\section{SOCIEDAD DEMOCRÁTICA Y POLÍTICA NACIONAL Y POPULAR: LA ARGENTINA EN LA PRIMERA MITAD DEL SIGLO XX \\ LUIS ALBERTO ROMERO}

Luis Alberto Romero es Investigador del CONICET con sede en la Universidad de Buenos Aires y miembro del Comité directivo del sitio historiapolítica.com

\section{Resumen}

En la primera mitad del siglo XX la sociedad argentina se caracterizó por su carácter democrático: crecimiento, integración, movilidad y un estilo fuertemente igualitario. Sus conflictos se relacionaron con la rápida incorporación y con la puja corporativa en torno del Estado. Los acompañó una inestabilidad identitaria, que derivó en un nacionalismo sustantivo. Sobre estos rasgos, la cultura política reunió la dimensión popular y la nacionalista con la valoración del Estado en la regulación de los conflictos. Estas ideas se esbozan en 1916 con el radicalismo yrigoyenista, se desarrollan luego de manera compleja y quebrada y plasman en 1945 con el peronismo, para instalarse sólidamente desde entonces en la cultura política.

\section{Summary}

In the first half of the twentieth century argentine society was characterized by its democratic nature: growth, integration, mobility and a strongly egalitarian style. Their conflicts were related to the rapid incorporation and corporate struggle around the State. They had been accompanied by an instable identity, which led to a substantive nationalism. On these terms, the political culture combined the popular nationalist dimension with the assessment of the State in regulating conflicts. These ideas are outlined in 1916 by the radicalism of Yrigoyen, then developed in complex ways and broken and reflected in 1945 by Peronism, to settle solidly since then in the political culture. 